straightforward in decrying the political influence in the United States of fundamentalist religious tenets on the teaching of evolution and the pursuit and application of research on embryos. Watson passionately objects to the current situation, in which US "politicians continue to pander to the outspoken religious minority". And he speaks for many scientists when he says: "I do not dispute the right of individuals to look to religion for a private moral compass, but I do object to the assumption of too many religious people that atheists live in a moral vacuum." These statements would be even more powerful if the chapter on recombinant DNA was not entitled "Playing God", thereby perpetuating a tool used by those who would inhibit modern genetics research.

The unfortunate errors aside, this book is more inclusive and is better reading than similar attempts by science journalists. Although aimed at a general audience, the ignorance among many biomedical scientists of the history of their science suggests that they too can learn a great deal from the book, and enjoy doing so.

Maxine Singer is president emeritus of the Carnegie Institution of Washington, 1530 P Street Northwest, Washington, DC, 20005, USA.

\section{A final call for peace}

The Hedgehog, the Fox, and the
Magister's Pox: Mending the Gap
Between Science and the
Humanities
by Stephen Jay Gould
Harmony: 2003.288 pp. $\$ 25.95$
Published in the UK on 29 May by Jonathan
Cape, E18.99
David Hull

Stephen Jay Gould's Rocks of Ages investigated the relationship between science and religion. In The Hedgehog, the Fox, and the Magister's Pox, published posthumously, Gould turns his attention to the relationship between science and the humanities. During the Renaissance, what we now term 'scientists' were at odds with humanists, whose goal was to recover the wisdom of antiquity, not to generate new ideas by means of empirical investigation. An appropriate mantra for Renaissance humanist scholars was 'been there, done that'. When the sciences cast off the heavy hand of the humanities in the Renaissance, a new adversarial attitude took its place. In this book, Gould strives to outline a more peaceful, mutually supportive view of the relationship between the sciences and the humanities.

Gould sees three ways in which the humanities can contribute to science. First, "science needs the humanities to teach us the quirky and richly subjective side of our own enterprise". The path of science does not run smoothly - at times it is indeed quirky. But is science really subjective, even richly subjective? Gould spends a lot of time debunking the myth of objectivity as a psychological characteristic of scientists. As anyone who studies science soon begins to realize, scientists are not very objective when it comes to their own work, but group objectivity is what matters. Individual scientists may lack objectivity when it comes to their own pet hypotheses, but others will happily take up the slack. Science is organized so that subjectivity can be reduced, resulting in as much objectivity as scientists need.

Gould warns of the great harm done in science and elsewhere by caricaturing one's opponents. The contrast between the traditional 'positivistic' views of science and more recent 'postmodernist' views is ripe for caricature. Supposedly, positivists think that scientists are infallible and provide absolute truth, whereas postmodernists insist that scientists are driven to come up with the views that they do primarily by such social forces as sexism, racism and homophobia. Gould tries to skate between these two extremes. Science is socially embedded, but the recognition of this fact can only aid scientists in their goal of recording and explaining the natural world.

A second contribution that the humanities can make to science is to help scientists improve their communication skills. Gould thinks that academics in general do not write well, with scientists especially deficient in this respect. One of the things that made Gould stand out from his contemporaries was that in general he wrote as well as any humanist ever has. Young academics in departments of English are stuck teaching courses in remedial writing, just as those of us in departments of philosophy are stuck teaching courses in remedial thinking, but neither group is likely to take much satisfaction from the goal that Gould has assigned them.

Finally, Gould claims that those of us in the humanities are charged with setting out the proper boundaries of all magisteria, including science. One of the weaknesses of this book is that Gould does not say enough about his central notion magisteria - and turning to a dictionary does not help. As far as I can tell, magisteria are something akin to areas of expertise shared by groups of experts. About the only characteristic that Gould attributes to magisteria is that they are non-overlapping. Positivists

took it as one of their tasks to define science. Quite a few philosophers of science today think that attempting to draw a line between science and everything else is not very helpful. There is no 'essence' to science, no set of attributes that characterizes all scientists and only scientists throughout all time. Science has evolved and continues to evolve. For some reason, Gould thinks that our concepts must be absolutely sharp to be of any use at all. Despite having a history, Gould argues, they have and must have an essence as well.

A second weakness of this book is that it is largely a collection of essays and parts of essays that have been welded into a single narrative. The seams show. Readers might wonder about the quirky, although arresting, title. The contrast between the hedgehog and the fox is initially meant to distinguish between being very good at one thing (the hedgehog curling up in a ball when attacked) and reasonably good at many things (the fox). He refers to this metaphor frequently in his book, but for me it doesn't add much to his exposition, and the Magister's pox hardly merits a mention except to rhyme with fox. Gould expends much effort arguing that science, once it is properly understood, is not in conflict with the humanities. But he says little about the help, if any, that science can give to the humanities.

Another reason why Gould introduces the notion of magisteria is to help usher in the Age of Aquarius, when peace will guide not only the planets but also academic disciplines. He himself has been badly burned, especially in connection with the controversy over E. O. Wilson's 'sociobiology'. Wouldn't everyone benefit if we all worked together and the lamb were to lie down with the lion? I too like peace and quiet,

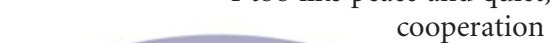

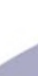

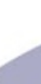


and generosity, and all areas of human endeavour can at times be characterized in these terms, but not often.

Why are people so loath to apply to themselves the basic principles that they apply to everyone else? Because it all depends on whose ox is being gored. Throughout this book, Gould preaches peace. In particular, he would like to end his conflict with Wilson, but in the final third of this book, Gould cannot resist taking one last swipe at his longtime adversary. Although Gould is as gentle and gentlemanly as possible, he attacks Wilson's reductionism under the guise of William Whewell's 'consilience of inductions'. A consilience of inductions occurs when the data used to support one hypothesis also turn out to support another hypothesis as well. Gould argues that Wilson has got Whewell all wrong: Whewell's notion of consilience is not in the least reductionistic.

In his final collection of essays, I Have Landed, Gould could not help wondering what comes next. Unfortunately, what came next was a second bout of cancer and premature death. But had he beaten the odds a second time, I think Gould would have continued to do battle with Wilson. I picture two warriors sinking into quicksand as they flail away at each other one more time just one more time.

David L. Hull is emeritus professor in the

Department of Philosophy, Northwestern

University, 1818 Hinman Avenue, Evanston, Illinois 60208-1315, USA.

\section{Einstein's view of Germany}

\section{Einstein in Berlin}

by Thomas Levenson

Bantam Doubleday Dell: 2003. 400 pp.

$\$ 25.95$

\section{Freeman J. Dyson}

Thomas Levenson is a film-maker who produces documentary films for public television. He has a sharp eye for the dramatic events and personal details that bring history to life. His latest book is a social history of Germany from 1914 to 1933, when Albert Einstein lived in Berlin. The picture of the city's troubles comes into clearer focus when viewed through Einstein's eyes. He was a good witness, observing the life of the city in which he played an active role but from which he remained emotionally detached.

Einstein wrote frequent letters to his old friends in Switzerland and his new friends in Germany, recording events as they happened and describing his hopes and fears. His daily life and activities come intermittently into the narrative, but are not the main theme. The main theme is the tragedy of the First World War, a tragedy that began in 1914 but

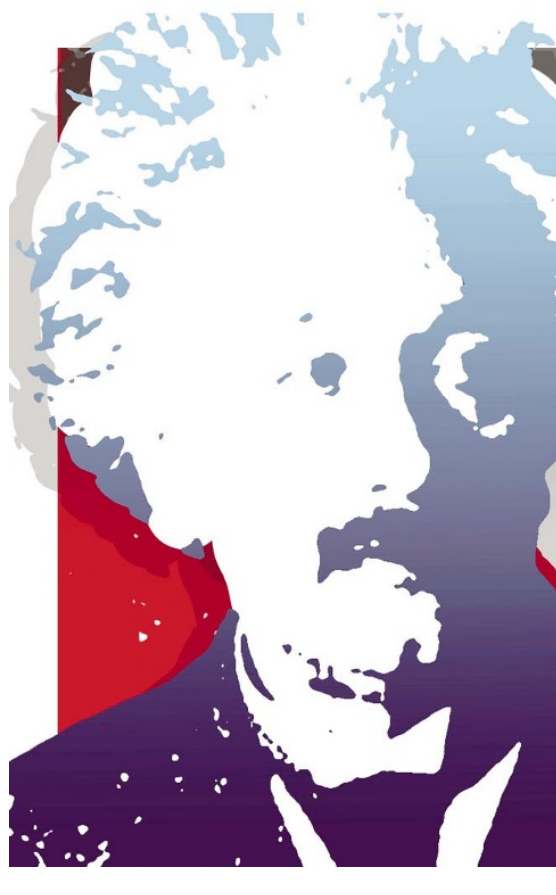

did not end with the war in 1918. It continued to torment the citizens of Berlin until 1933 , and led them finally to put their fate in the hands of Hitler. Hitler was able to gain power by promising to erase the tragedy and bring back the happy days of the empire when Germany was prosperous and united.

"There are, to be sure, too many biographies of Einstein and not enough of Poincaré," writes Peter Galison in a forthcoming book, Einstein's Clocks and Poincaré's Maps. Every aspect of Einstein's life - the personal, the political, the scientific and the philosophical - has been described in detail and analysed in depth by his various biographers. The world does not need another Einstein biography. Fortunately, Einstein in Berlin is not a biography. Levenson has borrowed everything he needs from the published correspondence and the existing biographies of Einstein, with full acknowledgements and an excellent bibliography. The new and original aspect of this book is the context in which Einstein is placed: an in-depth study of the social pathology that gripped Berlin from the day that Einstein arrived in 1914 to the day he left in 1932.

The tragedy is a play in two acts: the first act covers the years of war, and the second act the years of the Weimar Republic. The most remarkable feature of the first act is the general belief among Einstein's friends in Berlin that the war was winnable. The war was widely welcomed as an opportunity for Germany to achieve its proper status as a great power. Einstein observed that his academic friends and colleagues were even more deluded with patriotic dreams of grandeur than the ordinary citizens that he met in the street.

For example, in June 1918, after the last great German offensive on the Western front had failed, Felix Klein, a mathematician second only to David Hilbert in fame and authority, spoke in Göttingen to an audience of leading industrialists and government officials. He talked confidently of the coming victorious conclusion of the war, of the harmonious collaboration of German science with industry and the armed forces, and of the expected increase in support for mathematical education and research after the victory was won.

The state of mind of the mandarins in Berlin was very different from that of their enemies in Paris and London. In Paris the war was seen as a desperate struggle for survival. The guns on the Western front were so close that everyone in Paris could hear them. In Britain the war was seen as a tragedy that had done irreparable harm to Britain and to European civilization, no matter who won it. When the war came to an end in November 1918, the British public looked back on it as an unspeakable horror that should never under any circumstances be allowed to happen again. But a large part of the German public looked back on it differently, as a test of strength that they could have won if they had not been stabbed in the back by traitors at home. This book explains how that fatal German sense of betrayal came into being.

The second act of the tragedy is the story of the slow collapse of the Weimar Republic and the rapid rise of Hitler. Einstein was a firm supporter of the republic, but he saw which way the wind was blowing. One episode in the tragedy epitomizes the whole story. Erich Remarque's book Im Westen Nichts Neues was published in 1929 and immediately became an international bestseller. It is the finest fictional account of the First World War, as seen through the eyes of a group of young Germans who die pointlessly 